\title{
Clinical features, demography and predictors of outcomes of SARS-CoV-2 infection in a tertiary care hospital in India-A cohort study
}

Arunmozhimaran Elavarasi ${ }^{1 *}$; Hari Krishna Raju Sagiraju ${ }^{2 *}$; Rohit Kumar Garg; ${ }^{3}$ Saurav Sekhar Paul; ${ }^{3}$ Brajesh Ratre; ${ }^{4}$ Prashant Sirohiya; ${ }^{4}$ Nishkarsh Gupta; ${ }^{4}$ Rakesh Garg; ${ }^{4}$ Anuja Pandit; ${ }^{4}$ Saurabh Vig; ${ }^{4}$ Ram Singh; ${ }^{4}$ Balbir Kumar; ${ }^{4}$ Ved Prakash Meena; ${ }^{3}$ Naveet Wig; ${ }^{3}$ Saurabh Mittal; ${ }^{5}$ Saurabh Pahuja; $;$ Karan Madan ${ }^{5}$; Tanima Dwivedi; ${ }^{6}$ Nupur Das; ${ }^{6}$ Ritu Gupta; ${ }^{6}$ Ashima Jain Vidyarthi; ${ }^{7}$ Arghya Das; ${ }^{7}$ Rama Chaudhary; $;^{7}$ Laxmitej Wundawalli; ${ }^{8}$ Angel Rajan Singh; ${ }^{8}$ Sheetal Singh; ${ }^{8}$ Manisha Pandey; ${ }^{4}$ Abhinav Mishra; Karanvir Singh Matharoo; ${ }^{4}$ Sunil Kumar; ${ }^{9}$ Anant Mohan; ${ }^{5}$ Randeep Guleria; ${ }^{5}$ Sushma Bhatnagar \#

*Equal contributorship

1 Department of Neurology, All India Institute of Medical Sciences, New Delhi

2 Department of Preventive Oncology, All India Institute of Medical Sciences, New Delhi

3 Department of Medicine, All India Institute of Medical Sciences, New Delhi

4 Department of Onco-anesthesia and Palliative Medicine, All India Institute of Medical Sciences, New Delhi

5 Department of Pulmonary medicine, critical care and Sleep disorders, All India Institute of Medical Sciences, New Delhi

6 Department of Laboratory Oncology, All India Institute of Medical Sciences, New Delhi

7 Department of Microbiology, All India Institute of Medical Sciences, New Delhi

8 Department of Hospital Administration, All India Institute of Medical Sciences, New Delhi

9 Department of Surgical Oncology, All India Institute of Medical Sciences, New Delhi

\section{\#Corresponding Author}

Prof Sushma Bhatnagar

Head, Department of Onco-anesthesia and Palliative care

All India Institute of Medical Sciences, New Delhi

sushmabhatnagar1@gmail.com

Mobile:- +91-9811326453

Number of words: 3302

Number of tables: 6

Number of supplementary tables: 2

Number of references: 16

Number of figures: 2

Conflicts of interest: None of the authors report any conflict of interest

Funding: No funding was obtained 
medRxiv preprint doi: https://doi.org/10.1101/2021.08.10.21261855; this version posted August 30, 2021. The copyright holder for this preprint (which was not certified by peer review) is the author/funder, who has granted medRxiv a license to display the preprint in perpetuity.

All rights reserved. No reuse allowed without permission.

\section{Contributorship statement}

- Arunmozhimaran Elavarasi was involved in the conceptualization of the study, study design, patient care, data collection, statistical analysis, and in writing the first draft of the manuscript and agrees to be the guarantor of the manuscript taking responsibility for the integrity of the work as a whole, from incepton to published article

- Hari Krishna Raju Sagiraju was involved in the conceptualization of the study, study design, patient care, data collection, statistical analysis, and critique of the manuscript and agrees to be the guarantor of the manuscript taking responsibility for the integrity of the work as a whole, from incepton to published article

- Rohit Kumar Garg and Saurav Sekhar Paul was involved in the conceptualization of the study, study design, patient care and in the critique of the manuscript

- Brajesh Ratre, Prashant Sirohiya, Nishkarsh Gupta, Rakesh Garg, Anuja Pandit, Saurabh Vig, Ram Nalwa, Balbir Kumar were involved in study design, patient care and in the critique of the manuscript

- Ved Prakash Meena was involved in the study design, patient care and in the critique of the manuscript

- Naveet Wig was involved in the study design, patient care and in the critique of the manuscript

- Saurabh Mittal, Saurabh Pahuja, Karan Madan and Anant Mohan were involved in the study design, patient care and critique of the manuscript

- Tanima Dwivedi, Nupur Das and Ritu Gupta were involved in study conceptualization, in analyzing the laboratory parameters and in the critique of the manuscript

- Ashima Jain Vidyarthi, Arghya Das and Rama Chaudhary were involved in study conceptualization, in doing reporting the microbiology and in the critique of the manuscript

- Laxmitej Wundawalli, Angel Rajan Singh and Sheetal Singh were involved in coordinating staff for patient care, data collection and in the critique of the manuscript.

- Manisha Pandey, Abhinav Mishra and Karanvir Singh Matharoo were involved in patient care and in data collection

- Sunil Kumar was involved in the study design, patient care and in the critique of the manuscript

- Randeep Guleria was involved in the conceptualization of the study and final critique and review of the manuscript

- Sushma Bhatnagar was involved in the conceptualization of the study, convening of the working group, study design, patient care, and in final critique and review of the manuscript. 


\section{Clinical features, demography and predictors of outcomes of SARS-CoV-2 infection in a tertiary care hospital in India-A cohort study}

\section{Abstract}

\section{Background}

The second wave of the COVID-19 pandemic hit India from early April 2021 to June 2021 and more than 400,000 cases per day were reported in the country. We describe the clinical features, demography, treatment trends, baseline laboratory parameters of a cohort of patients admitted at the All India Institute of Medical Sciences, New Delhi with SARS-CoV-2 infection and their association with the outcome.

\section{Methods}

This was a retrospective cohort study describing the clinical, laboratory and treatment patterns of consecutive patients admitted with SARS-CoV-2 infection. Multivariate logistic regression models were fitted to identify the clinical and biochemical predictors of developing hypoxia, deterioration during the hospital stay and death.

\section{Findings}

A total of 2080 patients were included in the study. The case fatality rate was $19.5 \%$. Amongst the survivors, the median duration of hospital stay was 8 (5-11) days. Out of 853 (42.3\%\%) of patients who had COVID-19 Acute respiratory distress syndrome at presentation, 340 (39.9\%) died. Patients aged 4560 years [OR $(95 \% \mathrm{Cl}): 1.8(1.2-2.6) p=0.003$ ] and those aged $>60$ years [OR $(95 \% \mathrm{Cl}): 3.4(2.3-5.2)$, $\mathrm{p}<0.001$ ] had a higher odds of death as compared to the 18-44 age group. Vaccination reduced the odds of death by $30 \%$ [OR $(95 \% \mathrm{Cl}): 0.7(0.5-0.9), \mathrm{p}=0.036$ ]. Patients with hyper inflammation at baseline as suggested by leucocytosis [OR ( $95 \% \mathrm{Cl}): 2.1$ (1.4-3.10), $\mathrm{p}<0.001$ ], raised d-dimer $>500 \mathrm{mg} / \mathrm{dL}$ [OR $(95 \%$ $\mathrm{Cl}): 3.2(2.2-4.6), \mathrm{p}<0.001$ ] and raised $\mathrm{C}$-reactive peptide $>0.5 \mathrm{mg} / \mathrm{L}$ [OR $(95 \% \mathrm{Cl}): 3.8(1.1-13), \mathrm{p}=0.037]$ had higher odds of death. Patients who were admitted in the second week had lower odds of death and those admitted in the third week had higher odds of death.

\section{Interpretation}

This is the largest cohort of patients admitted with COVID-19 from India reported to date and has shown that vaccination status and early admission during the inflammatory phase can change the course of illness of these patients. Strategies should be made to improve vaccination rates and early admission of patients with moderate and severe COVID-19 to improve outcomes.

Key words: COVID-19; SARS-CoV-2; Predictors of outcomes; Vaccination 
medRxiv preprint doi: https://doi.org/10.1101/2021.08.10.21261855; this version posted August 30, 2021. The copyright holder for this preprint (which was not certified by peer review) is the author/funder, who has granted medRxiv a license to display the preprint in perpetuity.

All rights reserved. No reuse allowed without permission.

\section{Research in context}

\section{Evidence before this study}

The COVID-19 pandemic has been ravaging the world since December 2019 and the cases in various regions are being reported in waves. We found that the case fatality rates ranging from $1.4 \%$ to $28.3 \%$ have been reported in the first wave in India. Older age and the presence of comorbidities are known predictors of mortality. There are no reports regarding the effectiveness of vaccination, correlation of mortality with the timing of admission to the health care facility and inflammatory markers in the 'second wave' of the COVID-19 pandemic in India.

\section{Added-value of this study}

This study reports the real-world situation where patients get admitted at varying time points of their illness due to the mismatch between the availability of hospital beds and the rising number of COVID-19 patients during the pandemic. It reports the odds of developing severe hypoxia necessitating oxygen therapy and death thus helping identify priority groups for admission.

\section{Implications of all the available evidence}

This study found increased odds of requiring oxygen support or death in patients older than 45 years of age, with comorbidities, and those who had hyper-inflammation with raised C-reactive peptide, d-dimer or leukocytosis. Patients who were admitted in the second week of illness had lower odds of death as compared to those admitted in the third week implying that treatment with corticosteroids in the second week of the illness during the 'inflammatory phase' could lead to reduced mortality. These findings would help triage patients and provide guidance for developing admission policy during times where hospital beds are scarce. Vaccination was found to reduce the odds of deterioration or death and should be fast-tracked to prevent further 'waves' of the pandemic. 
medRxiv preprint doi: https://doi.org/10.1101/2021.08.10.21261855; this version posted August 30, 2021. The copyright holder for this preprint (which was not certified by peer review) is the author/funder, who has granted medRxiv a license to display the preprint in perpetuity. All rights reserved. No reuse allowed without permission.

\section{Introduction}

The SARS-CoV-2 infection has been declared a pandemic by the world health organization. To date, more than 200 million people have been infected by the virus and more than 4.26 million have died. ${ }^{1}$

The disease manifestation ranges from being completely asymptomatic and being detected only on screening due to a history of contact or may present with rapidly progressive hypoxic respiratory failure due to pneumonia and acute respiratory distress syndrome (ARDS).

The clinical features, demographic profile, severity at baseline and the case fatality rates differ between various geographic regions. We present these features and the predictors of outcomes in the Indian scenario during the 'second wave' of the COVID-19 pandemic in patients who were admitted to AlIMS, Jhajjar COVID-19 treatment facility. In the period from April to June 2021, this part of India was significantly affected by COVID-19 with many patients with nearly 30 percent positivity rates of tests conducted. The objectives of this study were to characterize the demographic, clinical, laboratory and imaging features, treatment trends and hospital outcomes in patients SARS-CoV-2 infection and to study the factors determining the outcomes in patients with SARS-CoV-2 infection.

\section{Methods}

This was a retrospective cohort study conducted at a tertiary care teaching institute at the National Cancer Institute, All India Institute of Medical Sciences (AIIMS), Jhajjar, India. The study protocol was approved by the Institutional review board. The protocol was designed keeping in mind the STROBE checklist for observational studies. The National Cancer Institute, AIIMS, Jhajjar is a dedicated oncology center that was converted into a designated COVID-19 treatment facility. This referral institute catered to a wide area of the northern part of India and COVID-19 patients were referred here from Delhi as well as from the nearby states of Haryana, Punjab, Rajasthan Uttar Pradesh and Bihar.

From the hospital electronic database, we included all consecutive patients admitted from the COVID-19 screening area of the hospital. We retrospectively abstracted the clinical data using a structured data capture form from the case files, screening forms and treatment sheets. Laboratory parameters and results of other biochemical \& microbiological reports were obtained from the hospital's electronic patient information portal. The demographic parameters like age, gender, comorbidity status, vaccination status, vital parameters including oxygen saturation at presentation, treatment administered, course during the hospital stay, lab parameters at baseline and during the hospital stay and the outcomes in terms of discharge or death at end of hospitalization, were collected. June 21 was considered to be the cutoff date to calculate case fatality rates.

\section{Case definitions}

SARS-CoV-2 infection: Patients with SARS-CoV-2 RNA detected on throat swab by RT-PCR or NAAT or SARS-CoV-2 antigen detected on Rapid antigen test.

Hypoxia: Any patient with oxygen saturation less than $94 \%$ on room air or needing oxygen $>21 \%$ to maintain saturation on a ventilator was considered to be hypoxic. 
medRxiv preprint doi: https://doi.org/10.1101/2021.08.10.21261855; this version posted August 30, 2021. The copyright holder for this preprint (which was not certified by peer review) is the author/funder, who has granted medRxiv a license to display the preprint in perpetuity.

All rights reserved. No reuse allowed without permission.

COVID-Pneumonia: Patients with SARS-CoV-2 infection as described above with breathlessness and chest infiltrates on chest Xray or CT scan of the chest

COVID-19 ARDS: Patients with SARS-CoV-2 pneumonia as described above with symptoms and hypoxia developing in 7 or fewer days from onset along with ARDS as per Berlin Definition 2012.

COVID-19 severity $^{3}$

Asymptomatic SARS-CoV-2 infection: Patients without symptoms of COVID-19 and positive for SARS-CoV-2 as described above.

Mild COVID-19: Patients with baseline oxygen saturation $\geq 94 \%$ without breathlessness but with other symptoms suggestive of COVID-19 such as fever, sore throat, myalgia, fatigue etc.

Moderate COVID-19: Patients with breathlessness and other symptoms suggestive of COVID-19 as described above, and with oxygen saturation $\geq 94 \%$

Severe COVID-19: Patients with COVID-19 symptoms as described above with an oxygen saturation $<94 \%$ or $\mathrm{PaO} 2 / \mathrm{FiO} 2<300$ or respiratory rate $>30 / \mathrm{min}$.

\section{Renal dysfunction:}

Biochemistry report with a creatinine $>1 \mathrm{mg} / \mathrm{dL}$ during the hospital stay or reduced urine output less than $0.5 \mathrm{~mL}$ per $\mathrm{kg}$ per hour or $<400 \mathrm{~mL}$ per day or requiring hemodialysis for metabolic acidosis, hyperkalemia or encephalopathy due to renal dysfunction, as described above.

\section{Hospital-acquired infection}

Biological samples from tracheal aspirates, urine, or blood cultures showing pathogens known to be associated with nosocomial infections.

Deteriorated during hospital stay: Patients who were not hypoxic at presentation, but went on to develop hypoxia; those who were on a face mask or non-rebreather mask receiving oxygen who went on to need high flow oxygen devices, non-invasive or invasive mechanical ventilation or those who needed renal replacement therapy for acute kidney injury which developed during the course of COVID-19.

Critical Illness: Development of respiratory failure necessitating mechanical ventilation, hypotension necessitating vasopressor support or renal dysfunction necessitating renal replacement therapy

Death: Patients who died due to any cause during the hospital stay

Death due to COVID-19: Death in which COVID-19 is the proximate or underlying cause of death according to the International guidelines for certification and classification (coding) of COVID-19as cause of death ${ }^{4}$

COVID-19 associated death: Cases where the associated COVID-19 infection could have aggravated the consequences of the primary illness or accident leading to death according to the International guidelines for certification and classification (coding) of COVID-19. ${ }^{4}$ 
medRxiv preprint doi: https://doi.org/10.1101/2021.08.10.21261855; this version posted August 30, 2021. The copyright holder for this preprint (which was not certified by peer review) is the author/funder, who has granted medRxiv a license to display the preprint in perpetuity.

All rights reserved. No reuse allowed without permission.

Discharge: Persons with SARS-CoV-2 infection who were discharged alive from the hospital. This includes those who were discharged home, those who left against medical advice and those who were transferred to another medical facility as described below.

Discharged home: Patients with SARS-CoV-2 infection who were discharged alive from the hospital after recovery and the destination from the hospital was home.

Left against medical advice: Patients with SARS-CoV-2 infection who were discharged alive from the hospital before reaching the discharged home criteria as described above. Such patients may continue their treatment at another hospital or choose to go home.

Transfer: Patients with SARS-CoV-2 infection who were discharged alive from the hospital to another health care facility to allow continued medical care for their primary illness or COVID-19 related complications.

The data collected for the purpose of the study were de-identified and analyzed. The patients included in this analysis will also be used in other reports to study subgroups and to answer other research questions.

\section{Statistical analysis}

The data were summarized using means and standard deviations for normal data and medians and interquartile ranges (p25-p75) for non-parametric data and means were compared using the 't test' and medians using the Wilcoxon rank-sum test. The categorical data were summarized as proportions and compared using the Chi2 test or Fisher's exact as appropriate. All statistical tests were performed with the use of a two-sided type I error rate of 5\%. Missing data were not imputed and the summary parameters were calculated with the available data and the denominators ( $n$ ) for each parameter was mentioned.

Univariate analysis was done to compare the various parameters between those who were discharged and those who died. Multivariate logistic regression analysis was done with models developed by including those that were found to be significant on univariate analysis as well as parameters of clinical relevance. We also included those parameters which we thought would influence the outcomes based on available scientific literature. Sensitivity analysis was done by dropping such parameters and by comparing the various models obtained by dropping them. Kaplan Meier survival probabilities were estimated by baseline severity status and were compared. All analysis was performed using STATAVersion 13.0 software.

\section{Results}

A total of 2080 patients were admitted to our COVID-19 facility during the period from April - June 2021. Amongst these, 17 were admitted as caregivers of the patients and 46 were still admitted at the facility as of the cut-off date of the study. Figure 1 shows the sample recruitment for the analysis of this study. 
medRxiv preprint doi: https://doi.org/10.1101/2021.08.10.21261855; this version posted August 30, 2021. The copyright holder for this preprint (which was not certified by peer review) is the author/funder, who has granted medRxiv a license to display the preprint in perpetuity. All rights reserved. No reuse allowed without permission.

\section{Case fatality rate and cause of death}

Out of the 2080 admitted patients, there were 406 deaths, which amounted to a case fatality rate of 19.5\%. In our cohort, 89 (21.9\%) patients died less than 48 hours after admission. The majority of patients $342(84.2 \%)$ died due to refractory hypoxia. We had 28 patients $(6.9 \%)$ who died due to myocarditis or sudden cardiac events such as pulmonary thromboembolism or myocardial infarction. Three patients were dead when they arrived at the emergency department. A minority of patients had acute kidney injury (5/406) and chronic kidney disease and uremia (2/406) as the cause of death. The other proximate causes of death were fall with head injury in one patient, SLE and related complications in two patients, febrile neutropenia and other complications of malignancy or chemotherapy (COVID-19 associated deaths) in eight patients, fungal pneumonia in 2 patients and mucor with fungal sepsis in four patients. The time to death and fraction of patients who were discharged at each time point has been categorized based on the severity of COVID-19 at presentation and the unadjusted odds are depicted in Figure 2.

\section{Clinical features and baseline characteristics}

Table 1 shows the sample characteristics of the 2017 patients who form the analysis cohort (Figure-1). Since this was a retrospective cohort study, we had missing data and it has been mentioned as to what proportion of the data points were missing for each of the parameters. 1763 (87.3\%) patients were admitted due to COVID-19 symptoms and 99 (4.9\%) patients were admitted for primarily non-COVID-19 indications such as malignancy, pancreatitis etc. and were found to be positive for SARS-CoV-2 during routine testing during the hospital stay. In our cohort, males 1355(65\%) outnumbered females 725 (35\%). We had 1572 patients who were discharged from the hospital cured or improved, 13 patients who left against medical advice and 26 patients who were transferred to other medical facilities for continuing care.

We found that around half of the patients (47\%) had severe disease at presentation (oxygen saturation of $<94 \%$ at baseline). Tachycardia, tachypnea and hypoxia at presentation were associated with increased odds of mortality on univariate analysis. Patients who had breathlessness and those who were drowsy or in altered sensorium had a higher odds of death. Sore throat, fatigue, myalgia, chest pain, gastrointestinal symptoms, loss of smell and taste were reported in higher proportions by patients who survived. This is likely due to the higher proportion of patients with severe disease, who probably could not narrate the history due to their respiratory distress. Breathlessness and altered sensorium on the other hand can be assessed by the examiner and could have been more accurately captured thus attaining significant differences between those who survived and those who died. Of note, $13.8 \%$ of patients presented with COVID-19 pneumonia and $47.4 \%$ of patients presented with COVID-19 related ARDS.

\section{Laboratory parameters}

The biochemical parameters of the cohort at baseline are detailed in Table 2. We found that patients with hyper inflammation as evidenced by leucocytosis, elevated C-reactive peptide and $d$-dimer were associated with higher odds of death. 
medRxiv preprint doi: https://doi.org/10.1101/2021.08.10.21261855; this version posted August 30, 2021. The copyright holder for this preprint (which was not certified by peer review) is the author/funder, who has granted medRxiv a license to display the preprint in perpetuity. All rights reserved. No reuse allowed without permission.

\section{Treatment trends}

The patients were treated by the team of intensive care physicians according to the clinical condition based on the national guidelines, institute protocols and latest scientific literature subject to availability of the interventions. In summary, almost all patients who were hypoxic and were on oxygen were treated with corticosteroids. All hypoxic patients without significant thrombocytopenia or other clear contraindications were treated with prophylactic doses of anticoagulation. The proportion of patients who were discharged and those who expired receiving various medications is detailed in Table 3. As expected, patients with severe disease were more likely to be treated with drugs such as pulse methylprednisolone, tocilizumab and remdesivir. Out of 256 patients who were treated with noninvasive ventilation, $221(86.3 \%)$ succumbed while only $13.7 \%$ of patients survived. Similarly, 250 patients received invasive mechanical ventilation, thereby representing $13.7 \%$ of the total cohort. Only $2.4 \%$ of those who received mechanical ventilation could be discharged and the rest succumbed to the illness.

\section{Predictors of outcome}

We analyzed the predictors of (i) developing severe illness needing oxygen therapy, (ii) deterioration during the hospital stay as defined above using the clinical and laboratory parameters at baseline are depicted in Tables 4 and 5 respectively. Predictors for the development of critical illness (as defined above) are depicted in supplementary table-1. The independent predictors of death were derived using logistic regression analysis and 4 models were created using the clinically relevant parameters as covariates. Adjusting for baseline clinical characteristics (Table-6, Model-1), age $>=45$ years, having comorbid conditions, Severe illness at presentation and hospitalization in the $3^{\text {rd }}$ week of illness were independently associated with increased odds of death. Vaccination and hospitalization in the $2^{\text {nd }}$ week of illness reduced the odds of death by $30 \%$ (OR $0.795 \% \mathrm{Cl} 0.5-0.9$ p-value 0.008 ) and $36 \%$ (OR $0.6495 \%$ $\mathrm{Cl}$ 0.48-0.86 p-value 0.003 ) respectively. The factors predicting deterioration in patients who were not hypoxic at baseline have been described in Supplementary table-2.

Leukocytosis, thrombocytopenia, elevated d-dimer, C-reactive peptide and creatinine at baseline independently predicted mortality after adjusting for other baseline and treatment characteristics. (Table-6, Model-3).

\section{Discussion}

This study describes the demography and clinical profile of the patients admitted to our facility during the 'second wave' of the COVID-19 pandemic. Few points are worthy of elaboration. Though the vaccination program had been started around 3 months before the rapid ascent in the curve, less than $2 \%$ of the patients who were admitted had received both the doses of vaccine at least 2 weeks before the infection and $14.2 \%$ were partially vaccinated. The designated COVID-19 facility catered to predominantly patients who were getting admitted due to COVID-19 pneumonia. We had around 5\% of patients who had other indications for admission such as malignancy. We found that getting admitted for other indications had a higher odds of death as compared to those who were admitted for COVID-19. Similarly, another interesting finding was that patients who got admitted in the third week [OR $3.395 \%$ Cl 1.1-9.7 $p=0.027]$ after symptom onset had a higher odds of death as compared to those getting 
medRxiv preprint doi: https://doi.org/10.1101/2021.08.10.21261855; this version posted August 30, 2021. The copyright holder for this preprint (which was not certified by peer review) is the author/funder, who has granted medRxiv a license to display the preprint in perpetuity. All rights reserved. No reuse allowed without permission.

admitted in the first week of onset of symptoms, while the odds of death was significantly lower [OR 0.6 $95 \% \mathrm{Cl}$ 0.5-0.8 95\% $\mathrm{Cl} 0.001$ ] when admitted during the second week of onset of symptoms compared to week-1. This probably could be because the initial first week was associated with fulminant viral pneumonia and those who present with severe disease at this early viraemic stage had a higher odds of death. Likewise, those who presented in the third week are likely to be those with inflammatory damage due to the 'cytokine storm'. These patients who presented in the third week are likely those who had not received corticosteroid therapy in the second week of the illness when the inflammatory phase had set in, probably leading to an increase in mortality. However, this hypothesis needs further study.

Our findings were different from the study by Chauhan et al. ${ }^{5}$ that showed more proportion of fever, fatigue, myalgia, abdominal pain in those who died as compared to those who survived. However, the study by Bairwa et al. ${ }^{6}$ concurred with the clinical symptomatology of our study. The case fatality rate of our cohort was $19.5 \%$ which was similar to that in multiple other studies. ${ }^{5-9}$ Another cohort from our center during the 'first wave' of the pandemic reported a Case fatality rate of $1.4 \% .{ }^{10}$ However a study from a tertiary care hospital in New Delhi reported a CFR of $28.3 \% .{ }^{11}$ The cohort of patients reported by Gupta et al. ${ }^{12}$ had a case fatality rate of $9.5 \%$ while the study by Wang et al. ${ }^{13}$ reported a CFR of $4.3 \%$. These differences could be due to various factors such as different strains of the virus, vaccination rates, usage of antiviral/anti-inflammatory agents and monoclonal antibodies, due to study design factors such as the proportion of patients still admitted and undergoing treatment at the end of the study or due to other baseline differences. Similar to these studies, a higher proportion of those with comorbidities and those with severe illness succumbed to the illness. In a subset of patients from this study who were over 18 years of age, and were eligible for vaccination, it was found that those who had completed the course of vaccination had $86 \%$ reduced odds of developing hypoxia and had a case fatality rate of $5.6 \%$ as compared to $22.8 \%$ in the unvaccinated group. ${ }^{14}$

Patients treated with methylprednisolone pulse therapy, remdesivir and tocilizumab had a higher odds of death as reflected in Table 4. This apparent paradox may be due to confounding by indication. Understandably, patients with severe disease and those with critical illness are more likely to be treated with these agents.

In our cohort, we had 1067 patients who needed oxygen and only 63\% of them survived. This implies a mortality rate of $37 \%$ in patients who needed some form of oxygen therapy or mechanical ventilation. This reflects the severe nature of COVID-19 pneumonia and ARDS in this cohort of patients. In a subset of patients of this cohort with hypoxia at presentation, it was found that the case fatality rate was $45.4 \%$ in those with silent hypoxia $40.03 \%$ in those with dyspneic hypoxia. ${ }^{15}$ More than $47 \%$ of patients of our cohort had ARDS due to COVID-19 pneumonia. Respiratory failure necessitating mechanical ventilation had a very poor prognosis with only $13.7 \%$ of those receiving non-invasive ventilation and $2.4 \%$ of those receiving invasive mechanical ventilation being discharged. It was disappointing that, almost $86 \%$ of patients who had to be ventilated died. This is probably due to the fulminant viral pneumonia in the initial week and hyperinflammatory lung disease during the second and third weeks of the illness. This is different from the historical mortality rates of ARDS. ${ }^{16}$ Similarly, all 12 patients who developed barotrauma-related pneumothorax or pneumomediastinum succumbed. The presence of renal 
medRxiv preprint doi: https://doi.org/10.1101/2021.08.10.21261855; this version posted August 30, 2021. The copyright holder for this preprint (which was not certified by peer review) is the author/funder, who has granted medRxiv a license to display the preprint in perpetuity. All rights reserved. No reuse allowed without permission.

dysfunction irrespective of the need for renal replacement therapy and hypotension were also independently associated with increased odds of mortality.

Our study includes a large cohort of patients which allows us to explore the various factors associated with severe illness, deterioration during hospitalization and death. However, it has a few limitations. Due to the retrospective nature of the data collection, few files had been misplaced or lost and nearly $10 \%$ of data points were missing. However, due to the large sample size of 2080 patients, we were able to find several independent risk factors for these outcomes. Similarly, due to the observational nature of the study, it is not possible to draw conclusions regarding causation. It is difficult to comment on the efficacy of for example high dose methylprednisolone pulses in preventing in-hospital deterioration because the drug had been administered at varying time points in the patients rather than a protocolized administration. In some patients, it had been administered once they needed oxygen administered through a high-flow nasal cannula while in others it was administered while on the verge of respiratory failure needing non-invasive ventilation. Similarly, the treatment was decided by the individual clinicians based on their discretion and thus subject to confounding by indication, thus precluding definite causation from being inferred. Other inflammatory markers such as raised ferritin and IL- 6 were also associated with increased odds of death, however, due to the low number of patients in whom these parameters were available at baseline, it was not included in the logistic regression models.

\section{Conclusion}

This is the largest cohort of COVID-19 patients that has been reported from the Southeast Asian region. Our study has also reported the relationship between the time of presentation and its association with mortality. We believe that early admission to the hospital, especially during the inflammatory phase, could make a difference by reducing mortality. Though during the first week or the viremic phase, we have no definite intervention to prevent mortality. Even remdesivir, which is an antiviral drug is effective in patients who are hypoxic but not critically ill and not in the early phase of the illness. Based on the available data, we could also conclude that vaccination has an impact on reducing the odds of death. However, once the patient develops ARDS related to COVID-19 necessitating respiratory support, the prognosis is dismal. Early administration of corticosteroids early in the inflammatory phase seems to be the only intervention that could have possibly changed the course of illness in our patients.

Data sharing: data collected for the study, including individual participant data and a data dictionary defining each field in the set, will be made available to others upon reasonable request to be routed through our Institute ethics committee with an appropriate protocol 
medRxiv preprint doi: https://doi.org/10.1101/2021.08.10.21261855; this version posted August 30, 2021. The copyright holder for this preprint (which was not certified by peer review) is the author/funder, who has granted medRxiv a license to display the preprint in perpetuity. All rights reserved. No reuse allowed without permission.

\section{References}

1. COVID Live Update: $200,672,639$ Cases and 4,265,820 Deaths from the Coronavirus Worldometer. Accessed August 4, 2021. https://www.worldometers.info/coronavirus/

2. Acute Respiratory Distress Syndrome: The Berlin Definition. JAMA. 2012;307(23). doi:10.1001/jama.2012.5669

3. Clinical Spectrum. COVID-19 Treatment Guidelines. Accessed July 19, 2021. https://www.covid19treatmentguidelines.nih.gov/overview/clinical-spectrum/

4. Guidelines_Cause_of_Death_COVID-19.pdf. Accessed July 19, 2021. https://www.who.int/classifications/icd/Guidelines_Cause_of_Death_COVID-19.pdf

5. Chauhan NK, Shadrach BJ, Garg MK, et al. Predictors of Clinical Outcomes in Adult COVID-19 Patients Admitted to a Tertiary Care Hospital in India: an analytical cross-sectional study. Acta BioMedica Atenei Parm. 2021;92(3):e2021024. doi:10.23750/abm.v92i3.10630

6. Bairwa M, Kumar R, Ajmal M, Bahurupi Y, Kant R. Predictors of critical illness and mortality based on symptoms and initial physical examination for patients with SARS-CoV-2: A retrospective cohort study. J Infect Public Health. 2021;14(8):1028-1034. doi:10.1016/j.jiph.2021.06.010

7. Gregoriano C, Koch D, Haubitz S, et al. Characteristics, predictors and outcomes among 99 patients hospitalised with COVID-19 in a tertiary care centre in Switzerland: an observational analysis. Swiss Med Wkly. 2020;150:w20316. doi:10.4414/smw.2020.20316

8. Albalawi O, Alharbi $\mathrm{Y}$, Bakouri $\mathrm{M}$, et al. Clinical characteristics and predictors of mortality among COVID-19 patients in Saudi Arabia. J Infect Public Health. 2021;14(8):994-1000.

doi:10.1016/j.jiph.2021.06.005

9. Zhang J-J, Cao Y-Y, Tan G, et al. Clinical, radiological, and laboratory characteristics and risk factors for severity and mortality of 289 hospitalized COVID-19 patients. Allergy. 2021;76(2):533-550. doi:10.1111/all.14496

10. Mohan A, Tiwari P, Bhatnagar S, et al. Clinico-demographic profile \& hospital outcomes of COVID19 patients admitted at a tertiary care centre in north India. Indian J Med Res. 2020;152(1 \& 2):6169. doi:10.4103/ijmr.IJMR_1788_20

11. Aggarwal A, Shrivastava A, Kumar A, Ali A. Clinical and Epidemiological Features of SARS-CoV-2 Patients in SARI Ward of a Tertiary Care Centre in New Delhi. J Assoc Physicians India. 2020;68(7):19-26.

12. Gupta N, Ish P, Kumar R, et al. Evaluation of the clinical profile, laboratory parameters and outcome of two hundred COVID-19 patients from a tertiary centre in India. Monaldi Arch Chest Dis Arch Monaldi Mal Torace. 2020;90(4). doi:10.4081/monaldi.2020.1507

13. Wang D, Hu B, Hu C, et al. Clinical Characteristics of 138 Hospitalized Patients With 2019 Novel Coronavirus-Infected Pneumonia in Wuhan, China. JAMA. 2020;323(11):1061-1069. doi:10.1001/jama.2020.1585 
medRxiv preprint doi: https://doi.org/10.1101/2021.08.10.21261855; this version posted August 30, 2021. The copyright holder for this preprint (which was not certified by peer review) is the author/funder, who has granted medRxiv a license to display the preprint in perpetuity. All rights reserved. No reuse allowed without permission.

14. Sagiraju HKR, Elavarasi A, Gupta N, et al. The Effectiveness of SARS-CoV-2 Vaccination in Preventing Severe IIIness and Death-Real-World Data from a Cohort of Patients Hospitalized with COVID-19.; 2021:2021.08.26.21262705. doi:10.1101/2021.08.26.21262705

15. Sirohiya P, Elavarasi A, Sagiraju HKR, et al. Silent Hypoxia in Coronavirus Disease-2019: Is It More Dangerous?-A Retrospective Cohort Study.; 2021:2021.08.26.21262668. doi:10.1101/2021.08.26.21262668

16. Bellani G, Laffey JG, Pham T, et al. Epidemiology, Patterns of Care, and Mortality for Patients With Acute Respiratory Distress Syndrome in Intensive Care Units in 50 Countries. JAMA. 2016;315(8):788. doi:10.1001/jama.2016.0291 
Figure 1: Patient recruitment and outcomes

Total number of patients included to calculate case fatality rate $n=2080$

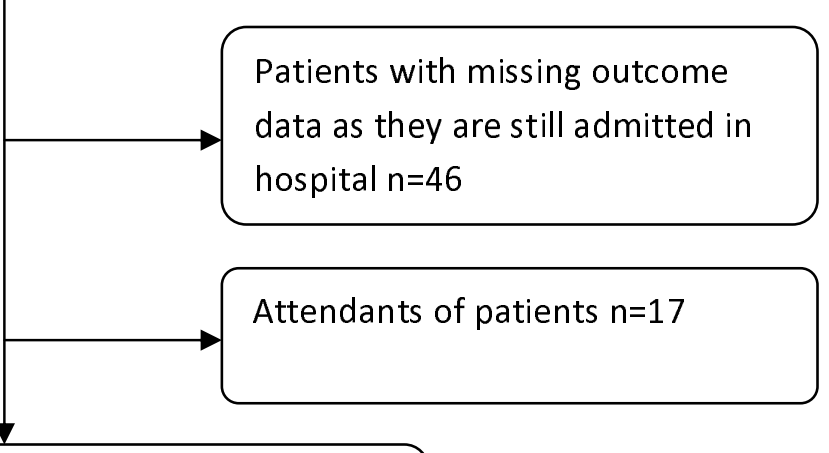

Number of patients with either baseline data or treatment data available to study predictors of outcomes $n=2017$

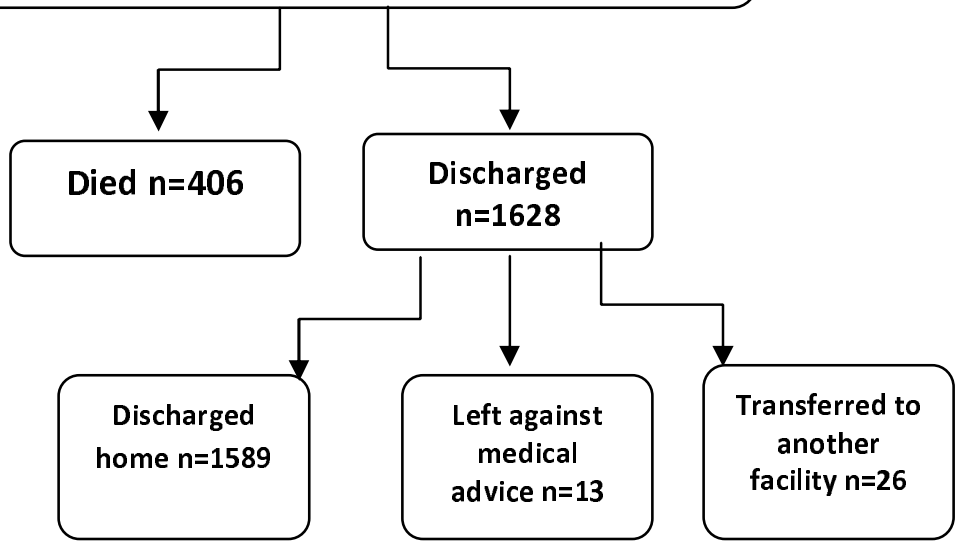


medRxiv preprint doi: https://doi.org/10.1101/2021.08.10.21261855; this version posted August 30, 2021. The copyright holder for this preprint (which was not certified by peer review) is the author/funder, who has granted medRxiv a license to display the preprint in perpetuity.

All rights reserved. No reuse allowed without permission.

Figure-2: Kaplan-Meier survival estimates by COVID-19 baseline severity.

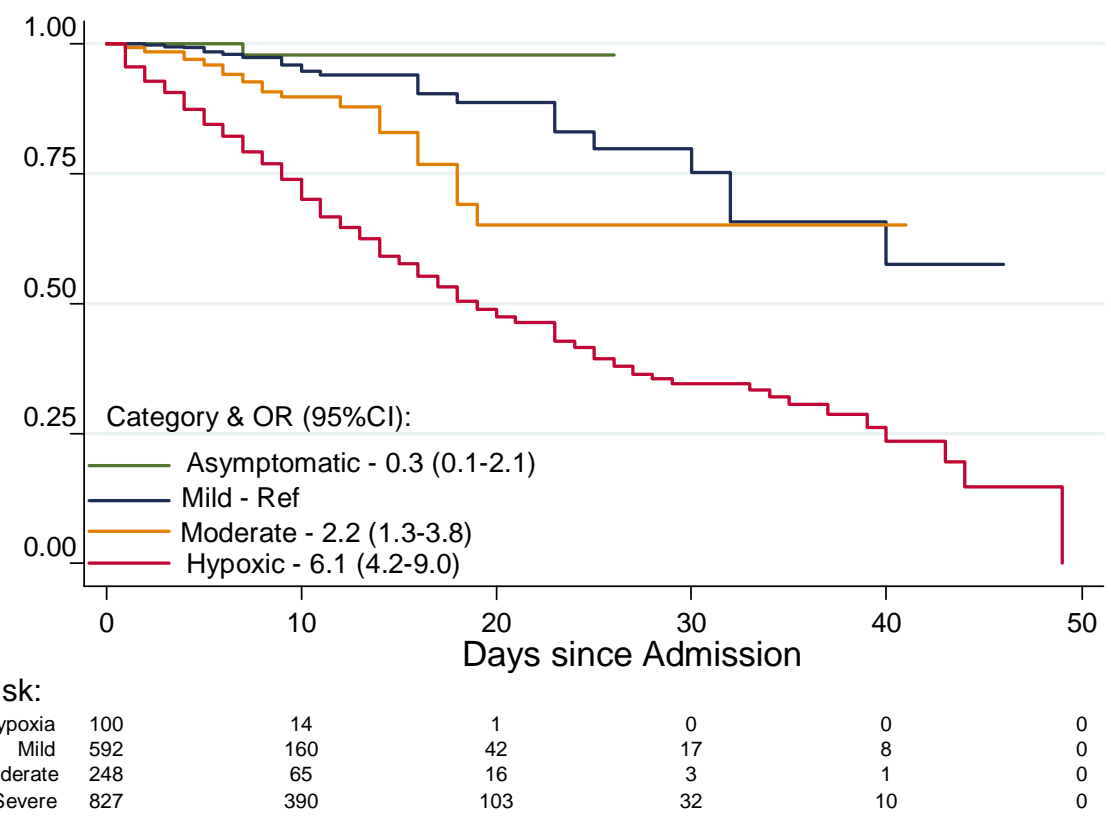

Figure Legends: Asymptomatic-Patients without symptoms of COVID-19

Mild-Patients with symptoms of COVID-19, but no breathlessness, SpO2 at baseline $\geq 94 \%$

Moderate-Patients with COVID-19 pneumonia and breathlessness, SpO2 at baseline $\geq 94 \%$

Severe-Patients with COVID-19 and severe hypoxia, SpO2 at baseline $<94 \%$ 
Table 1: Demographic and clinical profile of patients at baseline

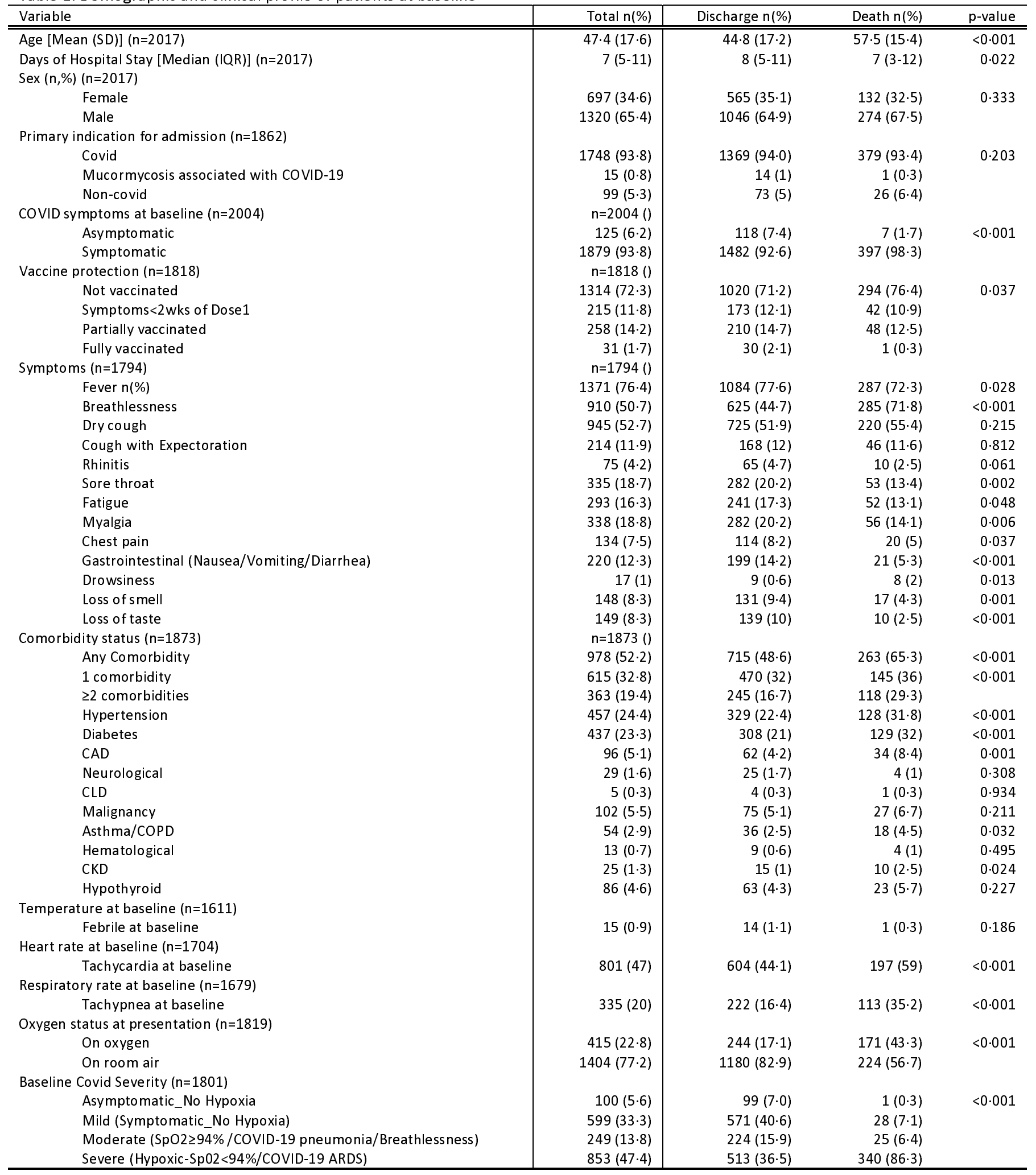


medRxiv preprint doi: https://doi.org/10.1101/2021.08.10.21261855; this version posted August 30, 2021. The copyright holder for this preprint (which was not certified by peer review) is the author/funder, who has granted medRxiv a license to display the preprint in perpetuity.

All rights reserved. No reuse allowed without permission.

Table 2: Laboratory parameters at baseline

\begin{tabular}{|c|c|c|c|c|c|}
\hline \multirow[b]{2}{*}{ Parameter } & \multicolumn{2}{|c|}{ Discharges } & \multicolumn{2}{|r|}{ Deaths } & \multirow[b]{2}{*}{$\mathrm{p}$ value* } \\
\hline & $\begin{array}{r}\text { Available } \\
\text { observations }\end{array}$ & $\begin{array}{r}\text { Mean(SD) or Median } \\
(p 25-p 75)\end{array}$ & $\begin{array}{r}\text { Available } \\
\text { observations }\end{array}$ & Mean(SD) or Median ( $\mathrm{p} 25-\mathrm{p} 75)$ & \\
\hline Hemoglobin (mg/dL) & 1322 & $12 \cdot 9(2 \cdot 2)$ & 334 & $12 \cdot 7(2 \cdot 2)$ & 0.051 \\
\hline Leucocyte count (cells $/ \mathrm{mm}^{3}$ ) & 1320 & $6.8(4 \cdot 8-9.9)$ & 332 & $11 \cdot 6(8 \cdot 1-15 \cdot 9)$ & $<0.001$ \\
\hline Neutrophil (cells $/ \mathrm{mm}^{3}$ ) & 1287 & $4 \cdot 8(2 \cdot 8-7 \cdot 8)$ & 320 & $10 \cdot 0(6 \cdot 6-13 \cdot 9)$ & $<0.001$ \\
\hline Lymphocytes (cells/mm³) & 1288 & $1.0(0.7-1.5)$ & 320 & $0.6(0.4-0.8)$ & $<0.001$ \\
\hline $\mathrm{LDH}(\mathrm{U} / \mathrm{L})$ & 1159 & $328(241-460)$ & 271 & $654(501-890)$ & $<0.001$ \\
\hline $\mathrm{T} \cdot$ Bilirubin (mg/dL) & 1341 & $0.5(0.4-0.7)$ & 339 & $0.6(0.4-0.9)$ & $<0.001$ \\
\hline $\operatorname{ALT}(U / L)$ & 1329 & $45(27-79)$ & 338 & $53(31-91)$ & 0.003 \\
\hline AST (U/L) & 1329 & $42(30-68)$ & 338 & $61(39-98)$ & $<0.001$ \\
\hline Globulin (g/dL) & 1315 & $2.6(0.4)$ & 336 & $2.7(0.5)$ & 0.002 \\
\hline A/G ratio & 1314 & $1.5(1.4-1.7)$ & 334 & $1 \cdot 3(1 \cdot 1-1 \cdot 5)$ & $<0.001$ \\
\hline Albumin $(\mathrm{g} / \mathrm{dL})$ & 1329 & $3.9(0.5)$ & 337 & $3.5(0.5)$ & $<0.001$ \\
\hline Urea $(\mathrm{mg} / \mathrm{dL})$ & 1351 & $30(21 \cdot 4-43 \cdot 0)$ & 338 & $59 \cdot 9(42 \cdot 8-87 \cdot 7)$ & $<0.001$ \\
\hline Creatinine $(\mathrm{mg} / \mathrm{dL})$ & 1351 & $0.7(0.6-0.9)$ & 338 & $0.9(0 \cdot 7-1 \cdot 3)$ & $<0.001$ \\
\hline Calcium (mg/dL) & 1323 & $8 \cdot 6(3 \cdot 6)$ & 338 & $8 \cdot 1(0 \cdot 8)$ & $<0.001$ \\
\hline Phosphate (mg/dL) & 1323 & $3.0(2 \cdot 5-3 \cdot 5)$ & 338 & $3 \cdot 1(2 \cdot 5-4 \cdot 0)$ & 0.005 \\
\hline Sodium (mEq/L) & 1341 & $137 \cdot 2(8 \cdot 3)$ & 339 & $139 \cdot 2(9 \cdot 7)$ & $<0.001$ \\
\hline Potassium (mEq/L) & 1341 & $4.5(4 \cdot 1-4.9)$ & 339 & $4 \cdot 7(4 \cdot 2-5 \cdot 2)$ & $<0.001$ \\
\hline \multicolumn{6}{|l|}{ Inflammatory markers } \\
\hline - $\quad$ Ferritin $(\mathrm{ng} / \mathrm{mL})$ & 473 & $365 \cdot 4(135 \cdot 2-878)$ & 116 & $1096 \cdot 5(712 \cdot 5-1650)$ & $<0.001$ \\
\hline - D-Dimer (ng/mL) & 1154 & $201 \cdot 5(121-347)$ & 271 & $622(337-2550)$ & $<0.001$ \\
\hline - $\quad \mathrm{CRP}(\mathrm{mg} / \mathrm{dL})$ & 1286 & $2 \cdot 6(0 \cdot 8-7 \cdot 4)$ & 301 & $9 \cdot 0(5 \cdot 1-16 \cdot 0)$ & $<0.001$ \\
\hline - $\quad \mathrm{IL}-6(\mathrm{pg} / \mathrm{mL})$ & 581 & $9 \cdot 1(3 \cdot 4-22 \cdot 6)$ & 195 & $40 \cdot 5(14 \cdot 4-104 \cdot 2)$ & $<0.001$ \\
\hline Categorical & $n$ & $n(\%)$ & $n$ & $n(\%)$ & chi2-pvalue \\
\hline Hemoglobin< $<12 \mathrm{~g} / \mathrm{dl}$ & 1322 & $378(28.6)$ & 334 & $111(33 \cdot 2)$ & 0.097 \\
\hline Thrombocytopenia $(<1.5$ Lac $)$ & 1329 & $269(20 \cdot 4)$ & 334 & $74(22 \cdot 2)$ & 0.439 \\
\hline Leucopenia & 1320 & $199(15 \cdot 1)$ & 332 & $15(4 \cdot 5)$ & $<0.001$ \\
\hline$L D H>246 U / L$ & 1159 & $853(73 \cdot 6)$ & 271 & $269(99 \cdot 3)$ & $<0.001$ \\
\hline Total Bilirubin $>1 \cdot 2 \mathrm{mg} / \mathrm{dl}$ & 1341 & $60(4 \cdot 5)$ & 339 & $29(8 \cdot 6)$ & 0.003 \\
\hline$A L T>49 U / L$ & 1329 & $605(45 \cdot 5)$ & 338 & $179(53.0)$ & 0.014 \\
\hline$A S T>=34 U / L$ & 1329 & $889(66.9)$ & 338 & $275(81 \cdot 4)$ & $<0.001$ \\
\hline Urea $>=50 \mathrm{mg} / \mathrm{dl}$ & 1351 & $242(17 \cdot 9)$ & 338 & $213(63 \cdot 0)$ & $<0.001$ \\
\hline Creatinine $>=1.0 \mathrm{mg} / \mathrm{dl}$ & 1351 & $53(3.9)$ & 338 & $88(26 \cdot 0)$ & $<0.001$ \\
\hline Hyperferritinemia $(>322 \mathrm{ng} / \mathrm{mL}$ ) & 473 & $250(52 \cdot 9)$ & 116 & $105(90 \cdot 5)$ & $<0.001$ \\
\hline $\mathrm{d}$-dimer $>500 \mathrm{ng} / \mathrm{ml}$ & 1154 & $188(16 \cdot 3)$ & 271 & $155(57 \cdot 2)$ & $<0.001$ \\
\hline $\mathrm{IL}-6>4.4 \mathrm{pg} / \mathrm{ml}$ & 581 & $410(70 \cdot 6)$ & 195 & $188(95 \cdot 4)$ & $<0.001$ \\
\hline CRP $>0.5 \mathrm{mg} / \mathrm{dl}$ & 1286 & $1031(80 \cdot 2 \%)$ & 301 & $298(99.0 \%)$ & $<0.001$ \\
\hline
\end{tabular}

Notes: $p$-values for means are calculated by t-test and for medians by Wilcoxon rank-sum test. 
medRxiv preprint doi: https://doi.org/10.1101/2021.08.10.21261855; this version posted August 30, 2021. The copyright holder for this preprint (which was not certified by peer review) is the author/funder, who has granted medRxiv a license to display the preprint in perpetuity.

All rights reserved. No reuse allowed without permission.

Table 3: Treatment offered and in-hospital complications

\begin{tabular}{|c|c|c|c|c|}
\hline & Total & Discharged & Died & chi2/Exact \\
\hline Parameter (n) & $\begin{array}{c}\mathrm{n} \text { (\% of observations } \\
\text { who received the } \\
\text { intervention) }\end{array}$ & $\mathrm{n}(\%)^{*}$ & $\mathrm{n}(\%)^{*}$ & $p$ value \\
\hline Oxygen $n=1831$ & $1025(56 \cdot 0)$ & $626(61 \cdot 1)$ & $399(38.9)$ & $<0.001$ \\
\hline HFNC $n=1808$ & $138(7 \cdot 6)$ & $42(30 \cdot 4)$ & $96(69 \cdot 6 \%)$ & $<0.001$ \\
\hline NIV $n=1823$ & $256(14 \cdot 0)$ & $35(13 \cdot 7)$ & $221(86 \cdot 3 \%)$ & $<0.001$ \\
\hline Invasive $\mathrm{MV}$ n=1830 & $250(13 \cdot 7)$ & $6(2 \cdot 4)$ & $244(97 \cdot 6)$ & $<0.001$ \\
\hline ICU admission n=2017 & $239(11 \cdot 9)$ & $99(41 \cdot 4)$ & $140(58 \cdot 6)$ & $<0.001$ \\
\hline Corticosteroid use ( $n=1813$ ) & $1094(60 \cdot 3)$ & $722(66 \cdot 0)$ & $372(34 \cdot 0)$ & $<0.001$ \\
\hline Pulse methylprednisolone $n=1752$ & $165(9 \cdot 4)$ & $52(31 \cdot 5)$ & $113(68 \cdot 5)$ & $<0.001$ \\
\hline Inhaled steroids n=1761 & $357(20 \cdot 3)$ & $247(69 \cdot 2)$ & $110(30 \cdot 8)$ & $<0.001$ \\
\hline Anticoagulation therapy $n=1796$ & $988(55 \cdot 0)$ & $658(66 \cdot 6)$ & $330(33 \cdot 4)$ & $<0.001$ \\
\hline Ivermectin $n=1758$ & $283(16 \cdot 1)$ & $235(83 \cdot 0)$ & $48(17 \cdot 0)$ & $0 \cdot 115$ \\
\hline Doxycycline $n=1757$ & $324(18 \cdot 4)$ & $246(75.9)$ & $78(24 \cdot 1)$ & 0.072 \\
\hline Minocycline $n=1757$ & $38(2 \cdot 2)$ & $29(76 \cdot 3)$ & $9(23 \cdot 7)$ & 0.615 \\
\hline Azithromycin $n=1754$ & $247(14 \cdot 1)$ & $195(79 \cdot 0)$ & $52(21 \cdot 1)$ & $0 \cdot 750$ \\
\hline Ceftriaxone $n=1757$ & $286(16 \cdot 3)$ & $172(60 \cdot 1)$ & $114(39.9)$ & $<0.001$ \\
\hline Levofloxacin $n=1760$ & $234(13 \cdot 3)$ & $98(41 \cdot 9)$ & $136(58 \cdot 1)$ & $<0.001$ \\
\hline Tocilizumab n=1755 & $37(2 \cdot 1)$ & $8(21 \cdot 6)$ & $29(78.4)$ & $<0.001$ \\
\hline Remdesivir $n=1755$ & $403(23 \cdot 0)$ & $257(63 \cdot 8)$ & $146(36 \cdot 2)$ & $<0.001$ \\
\hline Zinc $n=1687$ & $486(28 \cdot 8)$ & $440(90 \cdot 5)$ & $46(9.5)$ & $<0.001$ \\
\hline Hyperglycemia n=1660 & $402(24 \cdot 2)$ & $258(64 \cdot 2)$ & $144(35 \cdot 8)$ & $<0.001$ \\
\hline Renal dysfunction $n=1831$ & $340(18 \cdot 6)$ & $152(44 \cdot 7)$ & $188(55 \cdot 3)$ & $<0.001$ \\
\hline Hypotension $n=1800$ & $95(5 \cdot 3)$ & $3(3 \cdot 2)$ & $92(96.8)$ & $<0.001$ \\
\hline Hemodialysis $n=2017$ & $20(1 \cdot 0)$ & $6(30 \cdot 0)$ & $14(70 \cdot 0)$ & $<0.001$ \\
\hline Dialysis for AKI & $5(0 \cdot 25)$ & $1(20 \cdot 0)$ & $4(80 \cdot 0)$ & $<0.001$ \\
\hline
\end{tabular}


Table 4: Factors predicting the development of hypoxia requiring Oxygen Support

Oxygen Support during the hospital stay

\begin{tabular}{|c|c|c|c|}
\hline & & Model-1 & Model-2 \\
\hline & & OR(95\%Cl), p-value & OR(95\%Cl), p-value \\
\hline \multicolumn{4}{|l|}{ Age (Ref: 18-45yrs) } \\
\hline & $<18$ years & $0.5(0.2-0.9), 0.035$ & $0.2(0.1-0.8), 0.022$ \\
\hline & $45-60$ years & $2 \cdot 8(2 \cdot 1-3 \cdot 8),<0.001$ & $1.9(1 \cdot 3-2 \cdot 8), 0.001$ \\
\hline & $>60 \mathrm{yrs}$ & $2.8(2-4),<0.001$ & $1.6(1 \cdot 0-2 \cdot 6), 0.044$ \\
\hline Male (Ref: Female) & & $1 \cdot 2(1 \cdot 0-1 \cdot 6), 0 \cdot 094$ & $1 \cdot 0(0 \cdot 7-1 \cdot 5), 0 \cdot 846$ \\
\hline Vaccinated & & $0.6(0.5-0.8),<0.001$ & $0.7(0.5-0.9), 0.047$ \\
\hline \multicolumn{4}{|c|}{ Symptom onset to Hospitalization (Ref: 1week) } \\
\hline & 2weeks & $1 \cdot 2(0 \cdot 9-1 \cdot 5), 0 \cdot 248$ & $1 \cdot 0(0 \cdot 7-1 \cdot 4), 0.970$ \\
\hline & 3 or more weeks & $1.9(0 \cdot 47-8 \cdot 1), 0 \cdot 362$ & $2 \cdot 3(0 \cdot 3-20), 0 \cdot 463$ \\
\hline & Asymptomatic & $0.3(0.2-0.6),<0.001$ & $0.1(0.04-0.3),<0.001$ \\
\hline \multicolumn{4}{|l|}{ Symptoms reported (Ref: No) } \\
\hline & Breathlessness & $6 \cdot 4(5-8 \cdot 2),<0.001$ & $3 \cdot 7(2 \cdot 7-5 \cdot 2),<0.001$ \\
\hline & Dry cough & $1.3(1-1.7), 0.021$ & \\
\hline & Rhinitis & $0.5(0.3-0.8), 0.012$ & \\
\hline & Sore throat & $0.7(0.5-0.9), 0.021$ & \\
\hline & Fatigue & $0.7(0.5-0.9), 0.037$ & \\
\hline \multicolumn{4}{|l|}{ Comorbidities (Ref: No) } \\
\hline & 1 & $1.4(1-1.8), 0.032$ & $1 \cdot 3(0.9-1.9), 0.171$ \\
\hline & 2 or more & $1.7(1.2-2 \cdot 5), 0.003$ & $1 \cdot 6(1 \cdot 0-2 \cdot 6), 0.055$ \\
\hline \multicolumn{4}{|l|}{ Lab Parameters (Ref: No) } \\
\hline \multicolumn{4}{|c|}{ Leucocyte Count (Ref: Normal) } \\
\hline & Leukopenia & & $0.4(0.2-0.6),<0.001$ \\
\hline & Leukocytosis & & $2 \cdot 8(1.8-4 \cdot 3),<0.001$ \\
\hline D-Dimer $>500$ (Ref:=<500) & & & $2.5(1.6-3 \cdot 8),<0.001$ \\
\hline CRP high (Ref: Normal) & & & $5.7(3.4-9.7),<0.001$ \\
\hline Creatinine $>1.0 \mathrm{mg} / \mathrm{dl}$ & & & $1.7(1.1-2 \cdot 8), 0.024$ \\
\hline
\end{tabular}


Table 5: Factors predicting deterioration during the hospital stay

\begin{tabular}{|c|c|c|}
\hline & \multicolumn{2}{|c|}{ Deterioration during the hospital stay } \\
\hline & Model-1 & Model-2 \\
\hline & OR(95\% Cl), p-value & OR(95\%Cl), p-value \\
\hline \multicolumn{3}{|l|}{ Age (Ref: 18-45yrs) } \\
\hline$<18$ years & $0.6(0 \cdot 3-1 \cdot 4), 0.217$ & $0.5(0.1-2 \cdot 0), 0.336$ \\
\hline $45-60$ years & $1.8(1.3-2 \cdot 4),<0.001$ & $1 \cdot 5(1 \cdot 0-2 \cdot 2), 0 \cdot 040$ \\
\hline$>60$ years & $2.6(1.9-3.6),<0.001$ & $1 \cdot 8(1 \cdot 2-2 \cdot 7), 0.008$ \\
\hline Male (Ref: Female) & $1 \cdot 2(0 \cdot 9-1 \cdot 5), 0 \cdot 168$ & $0.9(0 \cdot 7-1 \cdot 3), 0.660$ \\
\hline \multicolumn{3}{|l|}{ Primary Condition (Ref: Covid) } \\
\hline Non-Covid & $2 \cdot 1(1 \cdot 2-3 \cdot 7), 0.012$ & $0.9(0 \cdot 4-2 \cdot 2), 0.825$ \\
\hline mucor & $1 \cdot 7(0 \cdot 1-20 \cdot 4), 0 \cdot 686$ & \\
\hline Vaccinated & $0 \cdot 8(0 \cdot 6-1 \cdot 0), 0 \cdot 067$ & $0 \cdot 8(0 \cdot 6-1 \cdot 1), 0 \cdot 140$ \\
\hline \multicolumn{3}{|c|}{ Time to Admission from Symptom Onset (Ref: 1 wk) } \\
\hline 2 weeks & $0.7(0.5-0.8), 0.001$ & $0.6(0.4-0.8), 0.001$ \\
\hline 3 or more weeks & $3 \cdot 1(1 \cdot 1-9 \cdot 6), 0.046$ & $2 \cdot 0(0 \cdot 4-10 \cdot 0), 0 \cdot 412$ \\
\hline Asymptomatic & $1 \cdot 0(0 \cdot 3-3 \cdot 7), 0 \cdot 948$ & $2 \cdot 3(0 \cdot 1-39 \cdot 0), 0 \cdot 572$ \\
\hline \multicolumn{3}{|l|}{ Comorbidities (Ref: No) } \\
\hline 1 & $1.3(1.02-1 \cdot 7), 0.037$ & $1 \cdot 3(0 \cdot 9-1 \cdot 9), 0 \cdot 107$ \\
\hline 2 or more & $1.6(1 \cdot 2-2 \cdot 2), 0.004$ & $1.5(1 \cdot 0-2 \cdot 2), 0.078$ \\
\hline \multicolumn{3}{|l|}{ Baseline COVID-19 severity (Ref: Mild) } \\
\hline Asymptomatic - No hypoxia & $0.2(0.1-0.8), 0.026$ & $0 \cdot 1(0 \cdot 0-2 \cdot 2), 0 \cdot 146$ \\
\hline Moderate & $2.4(1.7-3 \cdot 5),<0.001$ & $1.6(1.0-2 \cdot 6), 0.032$ \\
\hline Severe & $3.0(2 \cdot 3-4 \cdot 0),<0.001$ & $1 \cdot 1(0 \cdot 7-1 \cdot 6), 0.697$ \\
\hline \multicolumn{3}{|l|}{ Symptoms reported (Ref: No) } \\
\hline Fever & $0.7(0.5-0.9), 0.020$ & \\
\hline Dry cough & $1.3(1.1-1 \cdot 7), 0.020$ & $1.6(1 \cdot 2-2 \cdot 2), 0.002$ \\
\hline \multicolumn{3}{|l|}{ Lab Parameters (Ref: No) } \\
\hline Thrombocytopenia & & $1.8(1.2-2 \cdot 6), 0.004$ \\
\hline \multicolumn{3}{|l|}{ Leucocyte Count (Ref: Normal) } \\
\hline Leukopenia & & $0.5(0.3-0.8), 0.005$ \\
\hline Leukocytosis & & $2 \cdot 1(1 \cdot 5-2 \cdot 9),<0 \cdot 001$ \\
\hline D-Dimer $>500$ (Ref:=<500) & & $2.5(1.8-3.4),<0.001$ \\
\hline CRP high (Ref: Normal) & & $6.0(2 \cdot 8-13 \cdot 0),<0.001$ \\
\hline Creatinine $>1.0 \mathrm{mg} / \mathrm{dl}$ & & $2.2(1.5-3 \cdot 2),<0.001$ \\
\hline
\end{tabular}




\begin{tabular}{|c|c|c|c|c|}
\hline & Model-1 & Model-2 & Model-3 & Model-4 \\
\hline & OR(95\%Cl), p-value & OR(95\%Cl), p-value & OR(95\%Cl), p-value & OR(95\%Cl), p-value \\
\hline \multicolumn{5}{|l|}{ Age (Ref: 18-45years) } \\
\hline$<18$ years & $0.5(0.1-1 \cdot 7), 0.268$ & $0.6(0.1-5.8), 0.683$ & $2 \cdot 2(0.4-13), 0.367$ & $2(0.2-18), 0.519$ \\
\hline $45-60$ years & $1.8(1.2-2.6), 0.003$ & $2(1 \cdot 2-3 \cdot 3), 0 \cdot 012$ & $1.5(0.8-2.8), 0.220$ & $1.4(0.7-2 \cdot 8), 0.294$ \\
\hline$>60$ years & $3.4(2 \cdot 3-5 \cdot 2),<0.001$ & $2.8(1.6-4.9),<0.001$ & $2.5(1.3-4.8), 0.007$ & $2.4(1 \cdot 2-4 \cdot 8), 0.010$ \\
\hline Male (Ref: Female) & $1 \cdot 2(0 \cdot 89-1 \cdot 6), 0.223$ & 1 (0.67-1.5), 0.981 & $1(0.6-1.7), 0.940$ & $1.1(0.7-1.9), 0.734$ \\
\hline \multicolumn{5}{|l|}{ Primary Condition (Ref: Covid) } \\
\hline Non Covid & $3.5(1 \cdot 7-7 \cdot 1), 0.001$ & $1.2(0.4-3.5), 0.714$ & $0.8(0.3-2.6), 0.737$ & $0.5(0.1-1 \cdot 8), 0.285$ \\
\hline Mucor & $0.4(0.1-3 \cdot 6), 0.412$ & $0.9(0.1-11), 0.932$ & & \\
\hline \multicolumn{5}{|l|}{ Symptom onset to Hospitalization (Ref: 1Week) } \\
\hline 2 Weeks & $0.6(0.5-0.9), 0.003$ & $0.6(0.4-0.9), 0.028$ & $0.5(0.3-0.8), 0.003$ & $0.5(0.3-0.8), 0.004$ \\
\hline 3 or more weeks & $3.3(1.1-9.9), 0.034$ & $1.2(0 \cdot 2-6 \cdot 5), 0.842$ & $0.8(0.6-6 \cdot 2), 0.833$ & $0.3(0.01-16), 0.564$ \\
\hline Asymptomatic & $1 \cdot 1(0 \cdot 3-4 \cdot 2), 0.907$ & $6 \cdot 3(0 \cdot 2-143), 0.247$ & $12(0 \cdot 5-309), 0 \cdot 126$ & $0.01(0-\cdot), 0.984$ \\
\hline \multicolumn{5}{|l|}{ Comorbidities (Ref: No) } \\
\hline 1 & $1.5(1.1-2), 0.023$ & $1.6(1-2.5), 0.045$ & $2 \cdot 1(1 \cdot 2-3 \cdot 7), 0.006$ & $1.9(1-3.3), 0.035$ \\
\hline 2 or more & $1.8(1.2-2.6), 0.002$ & $1.6(1-2 \cdot 6), 0.072$ & $2.1(1.1-4), 0.017$ & $1.8(0.9-3.4), 0.080$ \\
\hline \multicolumn{5}{|l|}{ Baseline COVID-19 severity (Ref: Mild) } \\
\hline Asymptomatic - No hypoxia & $0.1(0.01-0.9), 0.049$ & $0.03(0.01-1 \cdot 1), 0.054$ & $0.02(0.01-0.82), 0.040$ & $5799(0-\cdot), 0.987$ \\
\hline Moderate & $2 \cdot 2(1 \cdot 2-4), 0.010$ & $1.5(0.73-3.2), 0.256$ & $1.5(0.7-3.6), 0.323$ & $1.4(0.6-3.5), 0.442$ \\
\hline \multicolumn{5}{|l|}{ Symptoms reported (Ref: No) } \\
\hline Fever & $0.6(0.4-0.8), 0.002$ & & & \\
\hline Gastrointestinal & $0.5(0.3-0.8), 0.008$ & $0.4(0.2-0.9), 0.020$ & $0.3(0.1-0.7), 0.008$ & $0.2(0.1-0.6), 0.006$ \\
\hline Loss of Taste & $0.5(0.2-0.9), 0.026$ & & & \\
\hline \multicolumn{5}{|l|}{ Lab Parameters (Ref: No) } \\
\hline Leukopenia & & $0.6(0.2-1.4), 0.198$ & $0.7(0.3-2), 0.527$ & $0.8(0.3-2.3), 0.73$ \\
\hline Leukocytosis & & $2 \cdot 1(1 \cdot 4-3 \cdot 1),<0 \cdot 001$ & $1.9(1 \cdot 1-3), 0.013$ & $1.9(1 \cdot 2-3 \cdot 2), 0.013$ \\
\hline Thrombocytopenia<1.5lac (Ref:>=1.5lac) & & $2.5(1.5-4),<0.001$ & $2 \cdot 2(1 \cdot 2-4), 0.007$ & $2 \cdot 1(1 \cdot 2-3.9), 0.016$ \\
\hline d-dimer $>500($ Ref: $=<500)$ & & $3 \cdot 2(2 \cdot 2-4 \cdot 6),<0 \cdot 001$ & $4.4(2 \cdot 8-7),<0.001$ & $4.4(2 \cdot 7-7 \cdot 3),<0.001$ \\
\hline CRP high (Ref: Normal) & & $3.8(1.1-13), 0.037$ & & \\
\hline Creatinine $>1 \cdot 0 \mathrm{mg} / \mathrm{dl}$ & & $2.5(1.6-3.9),<0.001$ & $3(1 \cdot 8-5 \cdot 1),<0.001$ & \\
\hline \multicolumn{5}{|l|}{ Treatment (Ref: No) } \\
\hline Methylprednisolone pulse (>250 mg/day) & & & $6.2(3.2-12),<0.001$ & $5.8(2.9-12),<0.001$ \\
\hline Levofloxacin & & & $5(2 \cdot 9-8 \cdot 8),<0 \cdot 001$ & $3.8(2-7 \cdot 1),<0.001$ \\
\hline Tocilizumab & & & $6.3(1.3-31), 0.023$ & $5.2(0.96-28), 0.056$ \\
\hline Zinc & & & $0.2(0.1-0.4),<0.001$ & $0.3(0.2-0.5),<0.001$ \\
\hline Anticoagulant therapy & & & $2 \cdot 4(1 \cdot 2-4.9), 0.013$ & $2.1(1-4 \cdot 3), 0.051$ \\
\hline \multicolumn{5}{|l|}{ In Hospital Complications } \\
\hline
\end{tabular}

Notes: Model-1: Adjusting for baseline clinical parameters, Model-2: Model-1 plus baseline lab parameters, Model-3: Model-2 plus treatment characteristics, Model-4: Model-3 plus in-

hospital complications. Age, gender and comorbidities are included in all models. Only symptoms, lab and treatment parameters with significant $\mathrm{p}$-value are included in these final

models. 
medRxiv preprint doi: https://doi.org/10.1101/2021.08.10.21261855; this version posted August 30, 2021. The copyright holder for this preprint (which was not certified by peer review) is the author/funder, who has granted medRxiv a license to display the preprint in perpetuity.

All rights reserved. No reuse allowed without permission.

Supplementary Table 1: Logistic regression model for developing Critical Illness

\begin{tabular}{|c|c|c|}
\hline & Model-1 & Model-2 \\
\hline & OR $(95 \% \mathrm{Cl}), \mathrm{p}$-value & OR $(95 \% \mathrm{Cl})$, p-value \\
\hline \multicolumn{3}{|l|}{ Age (Ref: 18-45yrs) } \\
\hline$<18$ years & $0 \cdot 9(0 \cdot 2-3 \cdot 1), 0 \cdot 818$ & -- \\
\hline $45-60$ years & $2 \cdot 1(1 \cdot 4-3 \cdot 1),<0.001$ & $2.5(1.5-4 \cdot 1), 0.001$ \\
\hline$>60$ years & $2.8(1.8-4 \cdot 2),<0.001$ & $2.5(1.5-4 \cdot 4), 0.001$ \\
\hline Male (Ref: Female) & $1.4(1-1.8), 0.048$ & $1 \cdot 3(0 \cdot 9-1 \cdot 9), 0 \cdot 223$ \\
\hline Vaccinated & $0.7(0.5-0.9), 0.023$ & $0.6(0.4-0.9), 0.035$ \\
\hline \multicolumn{3}{|l|}{ Symptom onset to Hospitalization (Ref: 1week) } \\
\hline 2weeks & $0.7(0.6-0.9), 0.040$ & $0 \cdot 8(0 \cdot 5-1 \cdot 1), 0 \cdot 152$ \\
\hline 3 or more weeks & $6.9(2 \cdot 1-22), 0.001$ & $3.9(0 \cdot 6-27 \cdot 0), 0.166$ \\
\hline Asymptomatic & $1 \cdot 3(0 \cdot 4-4 \cdot 7), 0 \cdot 712$ & $7 \cdot 3(0 \cdot 3-164 \cdot 0), 0 \cdot 211$ \\
\hline \multicolumn{3}{|l|}{ Comorbidities (Ref: No) } \\
\hline 1 & $1 \cdot 4(1 \cdot 0-2 \cdot 0), 0.035$ & $1 \cdot 5(1 \cdot 0-2 \cdot 3), 0 \cdot 081$ \\
\hline 2 or more & $1.9(1 \cdot 3-2 \cdot 8), 0.001$ & $1.7(1.1-2 \cdot 8), 0.029$ \\
\hline \multicolumn{3}{|l|}{ Baseline COVID-19 severity (Ref: Mild) } \\
\hline Asymptomatic - No Hypoxia & $0.22(0.02-2 \cdot 5), 0.221$ & $0.03(0.01-1.4), 0.075$ \\
\hline Moderate & $2.4(1.2-4 \cdot 5), 0.009$ & $1 \cdot 8(0 \cdot 8-3 \cdot 7), 0 \cdot 134$ \\
\hline Severe & $11(6 \cdot 6-17 \cdot 0),<0 \cdot 001$ & $4.9(2 \cdot 7-8 \cdot 7),<0.001$ \\
\hline \multicolumn{3}{|l|}{ Symptoms reported (Ref: No) } \\
\hline Gastrointestinal & $0.6(0.3-0.9), 0.034$ & $0.4(0.2-0.9), 0.04$ \\
\hline \multicolumn{3}{|l|}{ Lab Parameters (Ref: No) } \\
\hline \multicolumn{3}{|l|}{ Leucocyte Count (Ref: Normal) } \\
\hline Leukopenia & & $0 \cdot 6(0 \cdot 3-1 \cdot 5), 0.316$ \\
\hline Leukocytosis & & $2 \cdot 1(1 \cdot 4-3 \cdot 1),<0.001$ \\
\hline Thrombocytopenia<1.5lac (Ref:>=1.5lac) & & $2.4(1.5-3.9),<0.001$ \\
\hline D-Dimer $>500 \mathrm{ng} / \mathrm{ml}($ Ref: $\leq 500 \mathrm{ng} / \mathrm{ml})$ & & $2.9(2 \cdot 0-4 \cdot 2),<0.001$ \\
\hline CRP $>0.5 \mathrm{mg} / \mathrm{dl}(\operatorname{Ref}: \leq 0.5 \mathrm{mg} / \mathrm{dl})$ & & $3.8(1.1-13.0), 0.036$ \\
\hline Creatinine $>1.0 \mathrm{mg} / \mathrm{dl}$ (Ref: $\leq 1.0 \mathrm{mg} / \mathrm{dl}$ ) & & $2 \cdot 0(1 \cdot 3-3 \cdot 2), 0.001$ \\
\hline
\end{tabular}


medRxiv preprint doi: https://doi.org/10.1101/2021.08.10.21261855; this version posted August 30, 2021. The copyright holder for this preprint (which was not certified by peer review) is the author/funder, who has granted medRxiv a license to display the preprint in perpetuity.

All rights reserved. No reuse allowed without permission.

Supplementary Table 2: Factors predicting deterioration during hospital stay amongst those with no hypoxia at Baseline

\begin{tabular}{|c|c|c|}
\hline & Model-1 & Model-2 \\
\hline & OR(95\%Cl), p-value & OR(95\%Cl), p-value \\
\hline \multicolumn{3}{|l|}{ Age (Ref: 18-45years) } \\
\hline$<18$ years & $0.78(0.32-1 \cdot 88), 0.578$ & $0 \cdot 5(0 \cdot 1-2 \cdot 1), 0 \cdot 365$ \\
\hline $45-60$ years & $2 \cdot 1(1 \cdot 38-3 \cdot 19), 0.001$ & $1 \cdot 4(0 \cdot 8-2 \cdot 4), 0 \cdot 188$ \\
\hline$>60$ years & $2.44(1.52-3.91),<0.001$ & $1 \cdot 5(0.8-2 \cdot 7), 0 \cdot 213$ \\
\hline Male (Ref: Female) & $1.53(1.07-2.18), 0.02$ & $1 \cdot 1(0 \cdot 72-1 \cdot 8), 0 \cdot 588$ \\
\hline Vaccinated & $0.71(0.48-1 \cdot 05), 0.085$ & $0 \cdot 8(0 \cdot 49-1 \cdot 3), 0 \cdot 317$ \\
\hline \multicolumn{3}{|l|}{ Comorbidities (Ref: No) } \\
\hline 1 & $1.5(1.02-2.22), 0.041$ & $1 \cdot 2(0 \cdot 7-1 \cdot 9), 0.553$ \\
\hline 2 or more & $2.13(1.31-3.45), 0.002$ & $1.4(0.8-2 \cdot 6), 0.258$ \\
\hline \multicolumn{3}{|l|}{ Baseline COVID-19 severity (Ref: Mild) } \\
\hline Asymptomatic -No hypoxia & $0.36(0.14-0.94), 0.036$ & \\
\hline Moderate & $2.22(1.56-3.15),<0.001$ & \\
\hline \multicolumn{3}{|l|}{ Symptoms reported (Ref: No) } \\
\hline Dry cough & $1.49(1.05-2.1), 0.025$ & \\
\hline Gastrointestinal Symptoms & $1.95(1.28-2.97), 0.002$ & \\
\hline Fever & & $2.3(1.3-4), 0.003$ \\
\hline \multicolumn{3}{|l|}{ Lab Parameters (Ref: No) } \\
\hline \multicolumn{3}{|l|}{ Leucocyte Count (Ref: Normal) } \\
\hline Leukopenia & & $0.5(0.3-0.9), 0.026$ \\
\hline Leukocytosis & & $2 \cdot 3(1 \cdot 3-4 \cdot 0), 0.003$ \\
\hline D-Dimer $>500 \mathrm{ng} / \mathrm{ml}$ (Ref: $\leq 500 \mathrm{ng} / \mathrm{ml})$ & & $1.7(1 \cdot 0-3 \cdot 0), 0.047$ \\
\hline CRP $>0.5 \mathrm{mg} / \mathrm{dl}($ Ref: $\leq 0.5 \mathrm{mg} / \mathrm{dl})$ & & $9.4(3 \cdot 7-24 \cdot 0),<0.001$ \\
\hline Creatinine $>1.0 \mathrm{mg} / \mathrm{dl}($ Ref: $\leq 1 \cdot 0 \mathrm{mg} / \mathrm{dl})$ & & $2 \cdot 2(1 \cdot 2-3 \cdot 9), 0.010$ \\
\hline
\end{tabular}

